\title{
The Powder-pack Boriding Process: A Microstructure Comparison of Boride Layers Formed on AISI 4150 and M2 Steels
}

\author{
J. Zuno-Silva ${ }^{1}$, M. Ortiz-Domínguez ${ }^{1}$, I. Simón-Marmolejo ${ }^{1}$, L. E. Martínez-Martínez ${ }^{1}$, M. A. Flores- \\ Rentería $^{1}$, A. Arenas-Flores ${ }^{1}$, A. Cruz-Avilés ${ }^{1}$ \\ 1. Department of Mechanical Engineering, Universidad Autónoma del Estado de Hidalgo-Campus \\ Sahagún, Hidalgo, México.
}

Boriding is a thermochemical treatment in which boron atoms are diffused into the surface of a workpiece and form borides with the base metal. One basic advantage is that iron boride layers have extremely high hardness values (between 1600 and $2000 \mathrm{HV}$ ) [1]. The combination of a high surface hardness and a low surface coefficient of friction of the borided layer also makes a significant contribution in combating the main wear mechanisms: adhesion, tribooxidacion, abrasion, and surface fatigue [2-5]. In this study, the microstructure of the single phase layer $\left(\mathrm{Fe}_{2} \mathrm{~B}\right)$ and the double phase layer $\left(\mathrm{FeB}+\mathrm{Fe}_{2} \mathrm{~B}\right)$ have been investigated at different temperatures by the powder-pack method on the surface of AISI 4150 and AISI M2 steel.

The powder-pack boriding process was conducted on cubic commercial samples of AISI 4150 and AISI M2 with a thickness of $5 \mathrm{~mm}$. The samples were embedded in a closed in a closed cylindrical case (AISI 304L stainless steel) having a boron powder mixture inside with an average particle size of $30 \mu \mathrm{m}$. The boriding agent contained an active source of boron $\left(\mathrm{B}_{4} \mathrm{C}\right)$, an inert filler $(\mathrm{SiC})$, and an activator $\left(\mathrm{KBF}_{4}\right)$. The powder-pack boriding process was carried out in a conventional furnace under a pure argon atmosphere at 1223 and $1273 \mathrm{~K}$ for $8 \mathrm{~h}$ of exposure for each temperature. Once the boriding treatment was finished the container was removed from the furnace and slowly cooled to room temperature. The samples were cross-sectioned and resin-embedded for traditional metallographic preparation; the polished samples were etched in a $2 \%$ nital solution to observe the boride layer depths formed on the surface of AISI 4150 and AISI M2 steels. The boride layer depths and morphology were analysed by Scanning Electron Microscopy (SEM), Energy Dispersive Spectroscopy (EDS) and X-ray diffraction (XRD) patterns were collected on the surface of the borided AISI 4150 and M2 steels. Figure 1 shows the cross-sections of boride layers formed on the surface of AISI 4150 and AISI M2 steels at different temperatures and $8 \mathrm{~h}$ of exposure time. The resultant microstructure of a single-phase layer $\left(\mathrm{Fe}_{2} \mathrm{~B}\right.$ only) layers looks very dense, compact and homogenous, with sawtooth morphology. This particular morphology is ascribed to the presence of carbon and alloying elements in AISI 4150 (see Fig. 1a and Fig. 1b). Likewise, the formation of a double-phase layer $\left(\mathrm{FeB}+\mathrm{Fe}_{2} \mathrm{~B}\right)$ was revealed with a flat morphology (see Fig. 1c and Fig. 1d). This particular morphology is attributed to the presence of the alloying elements in the substrate of AISI M2 steel and can be explained by the existence of activated diffusion pathways in the $\mathrm{Fe}_{2} \mathrm{~B}$ and $\mathrm{FeB}$ crystal lattices. It is known that the alloying elements modify the morphology of $\left(\mathrm{FeB} / \mathrm{Fe}_{2} \mathrm{~B}\right.$ and $\mathrm{Fe}_{2} \mathrm{~B} /$ substrate $)$ interfaces and tend to concentrate at the tips of the boride needles by generating a flat morphology. The EDS analysis obtained by SEM at the $\left(\mathrm{Fe}_{2} \mathrm{~B} /\right.$ substrate) for the borided AISI 4150 steel is shown in Fig. 2a and for the borided AISI M2 steel is shown in Fig. 2b. The results of XRD studies presented in Fig. 3a and Fig. 3b show the XRD pattern recorded on the surface of borided AISI 4150 and M2 steels, respectively. They confirm that iron diboride $\left(\mathrm{Fe}_{2} \mathrm{~B}\right)$ on the surface of borided AISI 4150 steel. Likewise, the diffraction peaks relative to the iron boride $(\mathrm{FeB})$ and the iron diboride $\left(\mathrm{Fe}_{2} \mathrm{~B}\right)$ are easily identified on the surface of borided AISI M2. These results demonstrate that the powder-pack boriding process applied to AISI 4150 and M2 steels 
formed a single phase layer $\mathrm{Fe}_{2} \mathrm{~B}$ or a double phase layer $\left(\mathrm{FeB}+\mathrm{Fe}_{2} \mathrm{~B}\right)$ depending on the chemical composition.

References:

[1] Graf von Matuschka A. "Boronizing", $1^{\text {st }}$ ed. Carl Hanser Verlag, Munich, p. 12.

[2] J. R. Davis. "Surface Hardening of Steels: Understanding the Basics", 1 1st ed. ASM, Ohio, p. 213.

[3] Singhal S, Thin Solid Films, 45 (1977), p. 321.

[4] Yapar U. et al, Key Engineering Materials, 264 (2004), p. 633.

[5] T. W. Spence, M. M. Makhlouf, J. Materials Processing Technology, 168 (2005), p. 127.

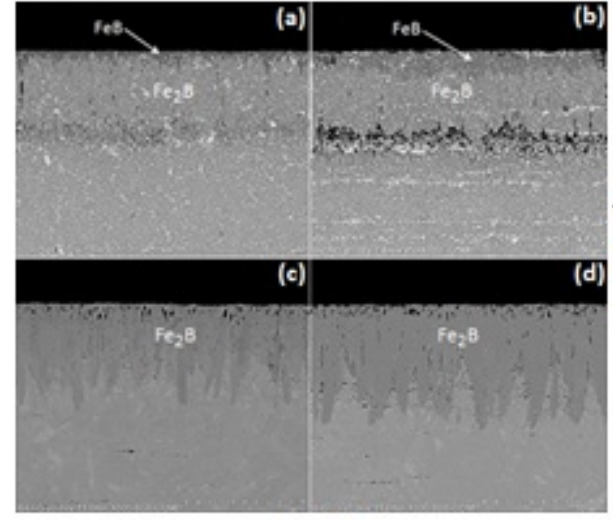

Fig. 1
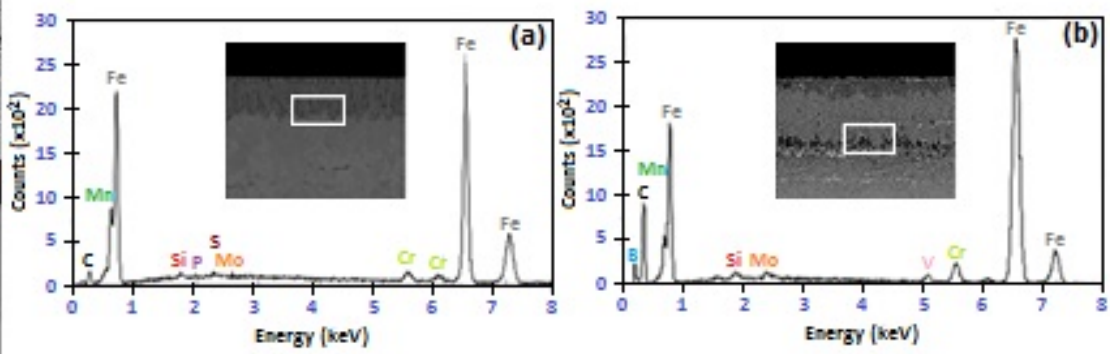

Fig. 2

Figure 1. Images (SEM) of cross-sections of borided: AISI M2 steel during 8 hours of treatment at temperatures: (a) $1223 \mathrm{~K}$ and (b) 1273; AISI 4150 steel during 8 hours of treatment at temperatures: (c) $1223 \mathrm{~K}$ and (d) 1273 and EDS (Figure 2) spectrum of borided samples at interfaces: (a) borided AISI 4150 and (b) M2 steels at $1273 \mathrm{~K}$ for 8 hours of treatment.

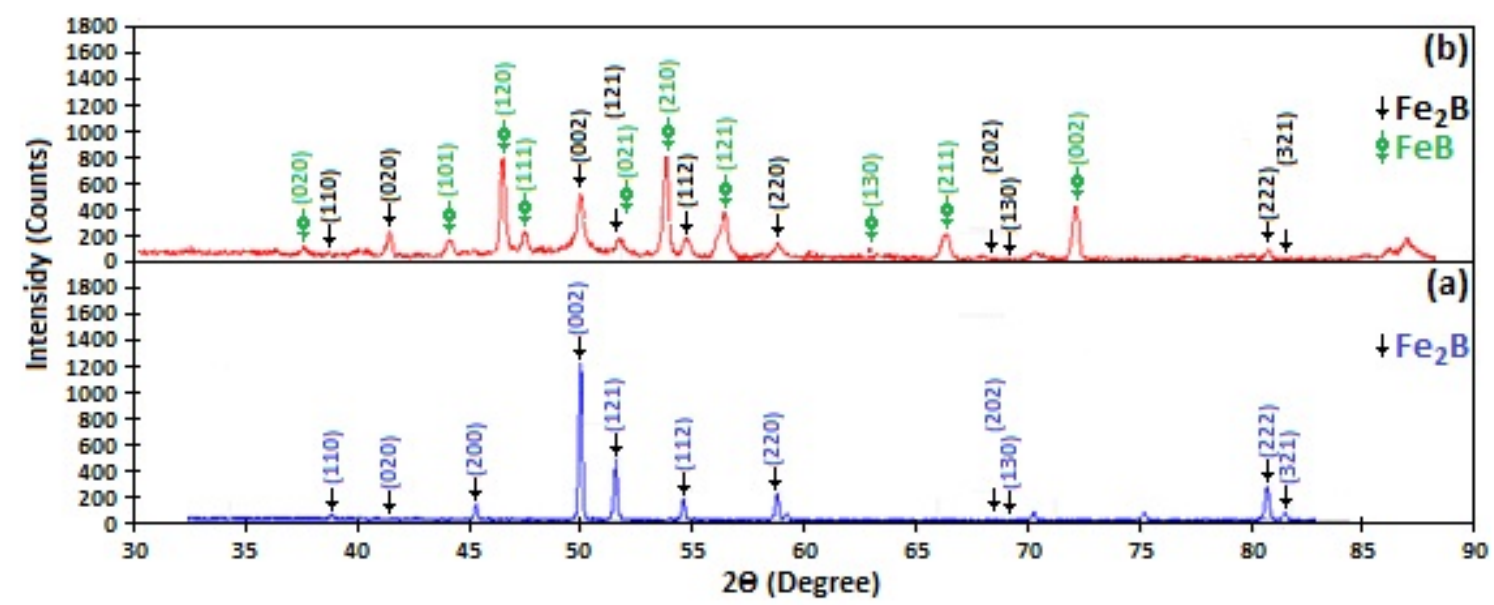

Figure 3. X-ray diffraction patterns obtained at the surface of: (a) borided AISI 4150 and (b) M2 steels at $1273 \mathrm{~K}$ for 8 hours of treatment respectively. 